\title{
POSISI DAN FUNGSI TEORI DALAM PENELITIAN KUALITATIF
}

\author{
Madekhan \\ madekhan.ali@gmail.com \\ FKIP, Universitas Islam Lamongan
}

\begin{abstract}
There is a growing interest on qualitative methodology as evidence by an increasing number of qualitative research design employed in social science researches. In qualitative inquiry process, the role of theory in the field of social science and where it situates in the research framework has always created a challenge for the researchers. However, inconclusive and differing opinions have so far been documented about the position and function of theory in qualitative research. The purpose of this paper is to build a general perspective in terms of the position and function of theory in qualitative research methodology applicable to social science research. Review of literatures on these issues were presented and discussed. As a result, mostly argue that theory in qualitative research is not in terms of testifying the validity or accuracy, event or experience in real-life cannot always or necessarily be based on theory, yet the significant role of theory in literature review is an undeniable fact. Here, theory is road guidance in qualitative research.
\end{abstract}

Key Words: Qualitative, Social Research, Position and Function of Theory

\section{PENDAHULUAN}

Setiap penelitian bermaksud untuk menemukan atau mengembangkan pengetahuan. Pengetahuan itu adakalanya berupa teori, yang merupakan penjelasan terhadap gejala-gejala, dan adakalanya berupa knowledge yang merupakan konsep-konsep atau pola- pola regulasi yang terdapat di alam ini. Selain itu, penelitian juga bermaksud untuk menemukan pengetahuan yang berupa strategi-strategi untuk pemecahan suatu masalah. Pada dasarnya penelitian kualitatif dapat digunakan untuk ketiga maksud tersebut (Bahar, 2011).

Untuk menggali ragam pengetahuan yang disebut di atas, penelitian kualitatif mempunyai caranya sendiri, yang berbeda dari penelitian kuantitatif. Jika penelitian kuantitatif bertolak dari suatu teori dan kemudian bermaksud untuk mengujinya, maka dalam penelitian kualitatif tidak demikian halnya. Penelitian kualitatif adalah penelitian yang bertolak dari ketidaktahuan, artinya peneliti belum memiliki pengetahuan tentang obyek yang diteliti, termasuk jenis data dan kategorikategori yang mungkin ditemukan. Karena itu, penelitian kualitatif tidak menggunakan teori yang sudah ada sebagai dasar pengembangan teoritiknya.

Penelitian kualitatif berangkat dari suatu komitmen untuk memperoleh data secara alamiah: peneliti beranggapan bahwa pemerolehan pengetahuan secara sistematik harus berada dalam suasana alamiah ketimbang dalam suasana artifisial atau buatan seperti eksperiman (Marshall dan Rossman (1989). Lebih sistematis dikemukakan Bryman (1988, hal 61-69) bahwa penelitian kualitatif memiliki 6 kriteria, sebagaimana dalam tabel 1 berikut:

Tabel 1. Kriteria Penelitian Kualitatif

\begin{tabular}{ll}
\hline 1 & $\begin{array}{l}\text { Melihat melalui mata dari ... atau menurut } \\
\text { perspektif subjek. }\end{array}$ \\
2 & $\begin{array}{l}\text { Menggambarkan detail-detail kebiasaan di } \\
\text { dalam kehidupan sehari-hari; }\end{array}$ \\
\hline
\end{tabular}




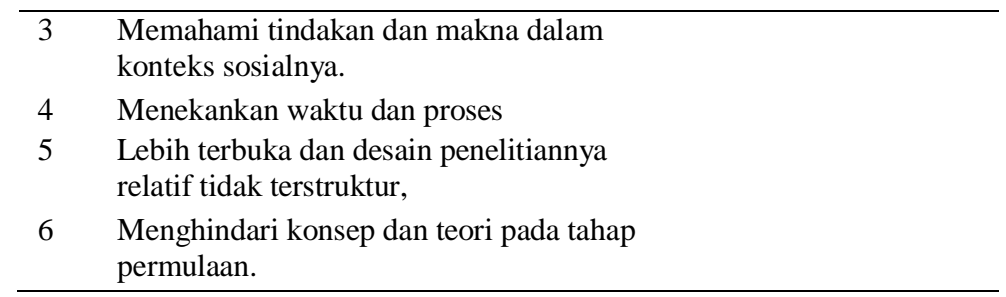

Bila mengacu Tabel 1 di atas maka Penelitian kualitatif adalah penelitian tentang riset yang bersifat deskriptif dan cenderung menggunakan analisis dengan pendekatan induktif. Proses dan makna (perspektif subyek) lebih ditonjolkan dalam penelitian kualitatif. Landasan teori dimanfaatkan sebagai pemandu agar fokus penelitian sesuai dengan fakta di lapangan. Selain itu landasan teori juga bermanfaat untuk memberikan gambaran umum tentang latar penelitian dan sebagai bahan pembahasan hasil penelitian.

Terdapat perbedaan mendasar antara peran landasan teori dalam penelitian kuantitatif dengan penelitian kualitatif. Dalam penelitian kuantitatif, penelitian berangkat dari teori menuju data, dan berakhir pada penerimaan atau penolakan terhadap teori yang digunakan. Sedangkan dalam penelitian kualitatif peneliti bertolak dari data yang sarat dengan konteks, memanfaatkan teori yang ada sebagai bahan penjelas, dan berakhir dengan suatu teori.

Penelitian kualitatif adalah penelitian yang temuan-temuannya tidak diperoleh melalui prosedur statistik atau bentuk hitungan lainnya, secara umum tujuan penelitian kualitatif adalah untuk "menemukan". Menemukan berarti sebelumnya belum pernah ada atau belum diketahui. Bisa dikatakan bahwa pendekatan kualitatif lebih menekankan pada esensi dari fenomena yang diteliti. Kebenaran dari hasil analisis penelitian kualitatif lebih bersifat ideographik, tidak dapat digeneralisasi. Hasil analisis penelitian kualitatif naturalistik lebih bersifat membangun, mengembangkan maupun menemukan teori-teori sosial. Dengan metode kualitatif, maka peneliti dapat menemukan pemahaman yang luas dan mendalam terhadap situasi sosial yang kompleks, memahami interaksi dalam situasi sosial tersebut sehingga dapat ditemukan hipotesis, pola hubungan yang akhirnya dapat dikembangkan menjadi teori.

\section{Pengertian Teori}

Teori adalah seperangkat dalil mengenai hubungan antara berbagai konsep. Dalam penelitian kualitatif, teori yang sudah ada memiliki kegunaan yang cukup penting, teori dalam penelitian kualitatif digunakan secara lebih longgar, teori memungkinkan dan membantu untuk memahami apa yang sudah diketahui secara intuitif pada saat pertama, tetapi bersifat jamak untuk berubah sebagaimana teori sosial berubah. Pada umumnya teori bagi penelitian kualitatif berguna sebagai sumber inspirasi dan pembanding (Bahar, 2011).

Kedudukan teori sendiri dalam penelitian hendaknya dipahami dari keterkaitannya dengan kedudukan hipotesis, metode dan metodologi. Pada tabel 1 di bawah ini, Silverman (1993, hal 1) dengan jelas menggambarkan kedudukan teori di tengah tiga konsep dasar dalam penelitian. 
Tabel 2. Konsep Dasar Dalam Penelitian

\begin{tabular}{lll}
\hline KONSEP & PENGERTIAN & RELEVANSI \\
Teori & Serangkaian konsep penjelas & Sesuai Kegunaan \\
Hypotesis & Pernyataan/proposisi yang bisa diuji & Validitas \\
Metodologi & Pendekatan umum untuk mengkaji topik penelitian & Sesuai Kegunaan \\
Metode & Suatu teknik penelitian tertentu. & $\begin{array}{l}\text { Harus sebangun dengan teori, } \\
\text { hipotesis dan metodologi }\end{array}$ \\
\hline
\end{tabular}

Sebagaimana pada tabel 2, teori menyediakan serangkaian konsep penjelas (explanatory concepts). Tanpa sebuah teori, tidak akan terlaksana penelitian. Di dalam penelitian sosial, contoh teori adalah fungsionalisme (yang mengkaji fungsi-fungsi pranata sosial), behaviorisme (yang melihat semua perilaku dalam kerangka stimulus dan respon), dan interaksi simbolik (yang memusatkan bagaimana kita mengkaitkan makna-makna simbolis dengan relasirelasi interpersonal.

Dengan demikian teori merupakan sumber tenaga bagi penelitian, dimana seiring perkembangan zaman, teori dikembangkan dan dimodifikasi oleh berbagai penelitian. Di sini diyakini bahwa ketika didayagunakan teori tidak pernah salah, namun hanya dalam pemahaman lebih ataupun kurang berguna Silverman (1993, hal 2).

Dalam penelitian kualitatif, karena permasalahan yang dibawa oleh peneliti bersifat sementara, maka teori yang digunakan dalam penelitian kualitatif juga bersifat sementara, dan akan berkembang setelah peneliti memasuki lapangan atau dalam konteks sosial. Dalam kaitannya dengan teori, penelitian kualitatif bersifat menemukan teori.

\section{Teori Bagi Peneliti Kualitatif}

Dari sisi kememadaian, dalam penelitian kualitatif yang bersifat holistik, jumlah teori yang harus dimiliki peneliti kualitatif jauh lebih banyak di bandingkan penelitian kuantitatif karena harus disesuaikan dengan fenomena yang berkembang di lapangan.

Peneliti kualitatif akan lebih profesional kalau menguasai semua teori sehingga wawasannya lebih luas, dan dapat menjadi instrumen penelitian yang baik. Teori bagi peneliti kualitatif akan berfungsi sebagai bekal untuk bisa memahami konteks sosial secara lebih luas dan mendalam. Walaupun peneliti kualitatif dituntut untuk menguasai teori yang luas dan mendalam, namun dalam melaksanakan penelitian, peneliti kualitatif harus mampu melepaskan teori yang dimiliki tersebut dan tidak digunakan sebagai panduan dalam menyusun instrument dan sebagai panduan dalam menyusun panduan untuk wawancara, dan observasi.

Peneliti kualitatif dituntut dapat menggali data berdasarkan apa yang diucapkan, dirasakan, dan dilakukan oleh partisipan atau sumber data. Peneliti kualitatif harus bersifat "perspektif emic" artinya memperoleh data bukan "sebagai seharusnya", bukan berdasarkan apa yang dipikirkan oleh peneliti tetapi berdasarkan sebagaimana adanya yang terjadi dilapangan, yang dialami, dirasakan, dan dipikirkan oleh partisipan/sumber data.

Oleh karena itu penelitian kualitatif jauh lebih sulit dari penelitian kuantitatif, karena peneliti kualitatif harus berbekal teori yang luas sehingga mampu menjadi "human instrument" yang baik. Penelitian kualitatif jauh lebih sulit bila 
dibandingkan dengan penelitian kuantitatif karena data yang terkumpul bersifat subyektif dan instrument sebagai alat pengumpul data adalah peneliti itu sendiri.

Dengan kebutuhan akan teori yang memadai, maka untuk dapat menjadi instrument penelitian yang baik, peneliti kualitatif dituntut untuk memiliki wawasan yang luas, baik wawasan teoritis maupun wawasan yang berkaitan dengan konteks sosial yang diteliti yang berupa nilai, budaya, keyakinan, hukum, adatistiadat yang terjadi dan berkembang pada konteks sosial tersebut. Bila peneliti tidak memiliki wawasan yang luas, maka peneliti akan sulit membuka pertanyaan pada sumber data, sulit memahami apa yang terjadi, tidak akan mampu memahami analisis secara induktif terhadap data yang diperoleh, padahal pendekatan induktif memberikan panekanan pada pemahaman yang kompresif atau "holistik" mengenai situasi sosial yang ditelaah. Artinya, kehidupan sosial dipandang sebagai pelibatan serangkaian peristiwa yang saling berpautan, yang perlu untuk digambarkan secara lengkap oleh peneliti kualitatif.

\section{Posisi dan Fungsi Teori Dalam Penelitian Kualitatif}

Menurut J.W Creswell (1998), peneliti kualitatif perlu menyadari perlunya dan tata cara penggunaan perspektif teori di dalam kajiannya. Ilmuilmu sosial memberikan penjelasan, prediksi dan generalisasi tentang bagaimana aspek-aspek kehidupan manusia berperan. Teori-teori tersebut mungkin diajukan oleh peneliti pada filosofis yang abstrak dan luas ataupun tingkat yang lebih konkrit dan substansial. Pertanyaan pokoknya, antara lain adalah: haruskah sebuah kacamata teori tertentu membingkai penelitian tersebut sehingga melahirkan pertanyaan penelitian dan menyarankan sudut pandang di dalamnya?
Yang jelas, bagaimanapun juga memang ada baiknya seorang peneliti untuk mempertimbangkan sebuah teori digunakan dalam penelitiannya. Pengertian membingkai di sini tidak lain adalah menggunakan sebuah teori ilmu tertentu untuk menginterpretasikan temuan penelitian dan bukan untuk menentukan variabel-variabel yang perlu ditemukan, apalagi untuk membuktikan kebenaran sebuah teori. Dapat dikatakan bahwa pada dasarnya penggunaan tersebut berada pada garis yang kontimum dari awal hingga akhir proses penelitian, tinggal pada posisi mana pada garis tersebut sebuah teori akan digunakan di masing-masing tradisi penelitian kualitatif, Mudzakir (2010).

Sementara Bahar

(2011), menyatakan bahwa posisi teori pada pendekatan kualitatif harus diletakkan sesuai dengan maksud penelitian yang dikerjakan. Pertama, untuk penelitian yang bermaksud menemukan teori dari dasar, paling tidak ada tiga aspek fungsi teori yang dapat dimanfaatkan;

a. Konsep-konsep yang ditemukan pada teori terdahulu dapat "dipinjam" sementara (sampai ditemukan konsep yang sebenarnya dari kancah) untuk merumuskan masalah, membangun kerangka berpikir, dan menyusun bahan wawancara;

b. Ketika peneliti sudah menemukan kategori-kategori dari data yang dikumpulkan, ia perlu memeriksa apakah sistem kategori serupa telah ada sebelumnya. Jika ya, maka peneliti perlu memahami tentang apa saja yang dikatakan oleh peneliti lain tentang kategori tersebut. Hal ini dilakukan hanya untuk perbandingan saja, bukan untuk mengikutinya; dan

c. Proposisi teoritik yang ditemukan dalam penelitian kualitatif (yang memiliki hubungan dengan teori yang sudah dikenal) merupakan sumbangan baru untuk memperluas teori yang 
sudah ada. Demikian pula, jika ternyata teori yang ditemukan identik dengan teori yang sudah ada, maka teori yang ada dapat dijadikan sebagai pengabsahan dari temuan baru itu.

Kedua, untuk penelitian yang bermaksud memperluas teori yang sudah ada, teori tersebut bermanfaat bagi peneliti pada tiga hal berikut;

a. Penelitian dapat dimulai dari teori terdahulu tersebut dengan merujuk kerangka umum teori itu. Dengan kata lain, kerangka teoritik yang sudah ada bisa digunakan untuk menginterpretasi dan mendekati data. Namun demikian, penelitian yang sekarang harus dikembangkan secara tersendiri dan terlepas dari teori sebelumnya. Dengan demikian, penelitian dapat dengan bebas memilih data yang dikumpulkan, sehingga memungkinkan teori awalnya dapat diubah, ditambah, atau dimodifikasi;

b. Teori yang sudah ada dapat dimanfaatkan untuk menyusun sejumlah pertanyaan atau menjadi pedoman dalam pengamatan/wawancara untuk mengumpul data awal; dan

c. Jika temuan penelitian sekarang berbeda dari teori yang sudah ada, maka peneliti dapat menjelaskan bagaimana dan mengapa temuannya berbeda dengan teori yang ada.

Peneliti kualitatif dituntut mampu mengorganisasikan semua teori yang dibaca. Landasan teori yang dituliskan dalam proposal penelitian lebih berfungsi untuk menunjukkan seberapa jauh peneliti memiliki teori dan memahami permasalahan yang diteliti walaupun permasalahan tersebut masih bersifat sementara. Oleh karena itu landasan teori yang dikemukakan bukan merupakan harga mati, tetapi bersifat sementara. Peneliti kualitatif justru dituntut untuk melakukan "grounded research", yaitu menemukan teori berdasarkan data yang diperoleh di lapangan.

Ada dua bentuk perangkat yang digunakan dalam merancang kerangka konseptual sebagai panduan kerja dalam penelitian kualitatif. Kedua perangkat dimaksud adalah "paradigma alamiah" (naturalistic paradigm) dan pola pengembangan pengetahuan dalam "bidang ilmu" yang diteliti. Pada dasarnya kedua perangkat ini bersifat saling melengkapi, di mana paradigma alamiah mengarahkan kegiatan penelitian, dari mana dimulai dan ke mana arahnya, serta bagaimana cara atau proses kerjanya, sedangkan bidang ilmu mempertegas obyek material atau substansi yang layak diteliti. Pandangan mendasar yang menjadi asumsi paradigma alamiah adalah bahwa dalam kehidupan bermasyarakat ada pola- pola interaksi atau perilaku tertentu yang terjadi secara ajeg.

Jika peneliti dapat mendeteksi dan menemukan pola-pola itu, maka ia dapat menyusunnya menjadi suatu teori. Inilah yang dimaksudkan dalam grounded theory bahwa penelitian kualitatif merupakan satu upaya untuk membangun teori dari dasar. Jadi, teori itu sesungguhnya ditemukan dari masyarakat melalui penelitian yang sistematis. Oleh karena itu, penelitian kualitatif sama sekali tidak bermaksud untuk menguji teori, dan bahkan tidak bertolak dari variabel-variabel yang direduksi dari suatu teori. Sungguh tidak relevan jika penelitian kualitatif dimulai dengan teori atau konsep/variabel yang digunakan teori sebelumnya, karena akan menghambat pengembangan rumusan teori baru.

Sejalan dengan asumsi di atas, peneliti kualitatif tidak membawa konsepkonsep yang diperoleh dari teori (yang sudah ada) ke lapangan, melainkan berusaha memahami dan memaknai fenomena sesuai dengan pemahaman dan 
pemaknaan yang diberikan oleh subyek yang diteliti. Ini sangat prinsip dalam penelitian kualitatif. Strategi ini disebut dengan pendekatan emik, yaitu suatu prinsip pemaknaan fenomena berdasarkan pemahaman "orang dalam", dengan menggunakan ukuran-ukuran yang ditemukan di lapangan. Dasar pijakan penelitian ini ialah adanya interaksi simbolik dari suatu gejala dengan gejala lain yang ditafsir berdasarkan pada budaya yang bersangkutan dengan cara mencari makna semantis universal dari gejala yang sedang diteliti. Bertolak dari prinsip paradigma alamiah, proses data kualitatif selalu menggunakan metode berpikir induktif. Prinsip pokok teknik analisa ini ialah mengolah dan menganalisa data menjadi data yang sistematik, teratur, terstruktur dan mempunyai makna. Tujuan akhir penelitian kualitatif ialah menghasilkan pengertian-pengertian, konsep-konsep dan atau pembangunan suatu teori baru. Perangkat yang kedua adalah pola pengembangan ilmu sosial, yang pada mulanya metode-metode kualitatif muncul dari penelitian-penelitian antropologi, etnologi, serta aliran fenomenologi dan aliran idealisme. Karena metode- metode ini bersifat umum dan terbuka maka ilmu sosial lainnya mengadopsi sebagai sarana penelitiannya.

Ada dua istilah yang sering dipakai dalam penelitian, kerangka teoritis dan kerangka konseptual. Istilah kerangka teoritis banyak dipakai dalam penelitian kuantitatif, tidak pada penelitian kualitatif, sedangkan istilah kerangka konseptual lebih tepat digunakan pada penelitian kualitatif. Dasar pertimbangannya adalah, bahwa penelitian kuantitatif menggunakan deduksi logis dari suatu teori untuk perumusan hipotesis, sedangkan penelitian kualitatif lebih pada upaya pembentukan konsep-konsep dari data lapangan menuju pemahaman terhadap fenomena atau terbentuknya suatu teori.
Pada hakikatnya, kerangka konseptual adalah suatu rancangan yang dapat menegaskan tentang dimensidimensi kajian utama penelitian serta mengungkap tentang perkiraan hubunganhubungan antara dimensi- dimensi tersebut. Atas dasar itu, kerangka konseptual merupakan panduan bagi peneliti dalam proses penelitiannya, baik memutuskan karakeristik data yang harus dikumpulkan, strategi dalam melakukan kategorisasi, maupun dalam penemuan relasi antara kategori.

Kapan waktu yang paling tepat melakukan perancangan kerangka konseptual dalam penelitian kualitatif? Ini menjadi diskusi yang tidak berujung di kalangan ahli kualitatif. Jika dilakukan dari awal, mungkin sekali membuat ketidakbebasan bagi peneliti untuk menemukan fenomena yang asli, karena pikirannya telah terfokus untuk memperhatikan hanya pada fokus khusus. Hal ini merupakan pengebirian karakter penelitian kualitatif. Tetapi jika kerangka konseptual dirancang belakangan, dapat mengakibatkan pengumpulan data serampangan dan bisa jadi menghadirkan data yang melimpah-ruah.

Diskusi yang tidak pernah selesai ini menjadi faktor munculnya berbagai pola perancangan kerangka konseptual di kalangan peneliti kualitatif. Ahli antropologi dan fenomenologi berpendapat, realitas sosial itu cukup kompleks, karena itu peta-peta konseptual yang konvensional akan menjadi kendala. Sebab, latar, fenomena-fenomena, dan pelaku-pelaku yang paling bermakna tidak akan dapat diramalkan sebelum penelitian lapangan. Jadi, kerangka konseptual seharusnya muncul secara empiris di lapangan sewaktu penelitian berjalan.

Tidak semua penelitian harus menghasilkan teori. Sebagian dari hasil penelitian itu tidak dimungkinkan untuk dilanjutkan ke perumusan teori, dan 
karena itu harus dihentikan sampai pada penemuan formulasi- formulasi konseptual dan tema-tema budaya. Penelitian yang sampai pada penemuan tema-tema seperti itu juga cukup penting, sebab tema-tema yang memuat keterangan deskriptif itu dapat disusun secara sistematis ke dalam bentuk konsepsi -konsepsi dekriptif yang kaya dengan definisi, informasi, dan atau abstraksi dari gejala-gejala sosial. Atas dasar itu, seorang peneliti kualiatif tidak mesti memaksakan diri untuk menemukan "teori" dari kancah, bahkan ia dapat saja merancang sebuah penelitian yang hanya sampai pada penemuan tematema untuk disusun ke dalam pengetahuan deskriptif yang bersifat informatif.

Akhirnya, perumusan teori dimulai dengan mereduksi jumlah kategorikategori sekaligus memperbaiki rumusan dan integrasinya. Modifikasi rumusan semakin minimal, sekaligus isi data dapat terus semakin diperbanyak. Atribut terori yang tersusun dari hasil penafsiran/pemaknaan dilengkapi terus dengan data baru, dirumuskan kembali dalam arti diperluas cakupannya sekaligus dipersempit kategorinya. Jika hal itu sudah tercapai dan peneliti telah merasa yakin akan hasilnya, pada saat itu peneliti sudah dapat mempublikasikan hasil penelitiannya.

\section{KESIMPULAN}

Dasar penelitian kualitatif berada di seputar upaya memperoleh data secara alamiah. Bagaimana peneliti berupaya memperoleh pengetahuan secara sistematik dalam suasana alamiah, tidak artifisial atau buatan. Atas sifatnya demikian, maka teori dalam penelitian kualitatif, memiliki kegunaan yang cukup penting. Teori dalam penelitian kualitatif digunakan untuk memungkinkan dan membantu peneliti kualitatif memahami apa yang sudah diketahui secara intuitif pada saat pertama, tetapi pada fase berikutnya bisa berubah sebagaimana teori sosial berubah.

Peneliti kualitatif akan lebih profesional kalau menguasai semua teori sehingga wawasannya lebih luas, dan dapat menjadi instrumen penelitian yang baik. Teori bagi peneliti kualitatif akan berfungsi sebagai bekal untuk bisa memahami konteks sosial secara lebih luas dan mendalam. Oleh karena itu penelitian kualitatif jauh lebih sulit dari penelitian kuantitatif, karena peneliti kualitatif harus berbekal teori yang luas sehingga mampu menjadi "human instrument" yang baik. Penelitian kualitatif jauh lebih sulit bila dibandingkan dengan penelitian kuantitatif karena data yang terkumpul bersifat subyektif dan instrument sebagai alat pengumpul data adalah peneliti itu sendiri.

Fungsi dan posisi sebuah teori dalam pengertian sederhana adalah bingkai dari sebuah penelitian kualitatif. Di sini tidak lain adalah menggunakan sebuah teori ilmu tertentu untuk menginterpretasikan temuan penelitian dan bukan untuk menentukan variabelvariabel yang perlu ditemukan, apalagi untuk membuktikan kebenaran sebuah teori. Dapat dikatakan bahwa pada dasarnya, fungsi dan posisi teori berada pada garis yang kontimum dari awal hingga akhir proses penelitian, tinggal pada posisi mana pada garis tersebut sebuah teori akan digunakan di masingmasing tradisi penelitian kualitatif.

Akhrinya, sebagaimana ditemukan dalam beberapa literatur metode penelitian (Moleong, 1999; Creswell, 2002, Lindloft, 1995), menyebutkan bahwa metode penelitian kualitatif lebih bersifat induktif. Artinya langkah penelitian yang harus didahulukan adalah data berdasarkan fakta, gejala, fenomena, realitas yang menjadi tema, kemudian diolah, diproses, sehingga akhir penelitian dapat menjadi proposisi, model atau bahkan teori. Hampir semua disepakati bahwa teori pada 
penelitian kualitatif bukan untuk diuji keabsahan, kebenaran atau kesalahannya, melainkan sebagai "guidance" atau "petunjuk jalan" saja.

\section{DAFTAR PUSTAKA}

Bahar, Hartati, Teori dalam Penelitian Kualitatif,http://tatikbahar.blogspot .com/2011/01/teori- dalampenelitian-kualitatif.html, diakses November 2012.

David, Silverman, Interpreting Qualitative Data, Sage Publication, London, 1993.

Gempur Santoso, Fundamental Metodologi Penelitian Kuantitatif dan Kualitatif, Cetakan pertama: Juli 2005, Prestasi Pustaka Publisher, Jakarta, 2005.

Moedzakir, Djauzi, M.A, Desain dan Model Penelitian Kualitatif, Universitas Negeri Malang, 2010

Moleong, Lexy J., Metodologi Penelitian Kualitatif, Bandung: Remaja Rosdakarya, 1990.

Purwoko, Bambang, Penelitian Kualitatif, Bahan Kuliah S2 Politik Lokal dan Otonomi Daerah, Universitas Gajah Mada, 2008.

Siregar, Parluhutan. Teori dan Kerangka Konseptual, http://google.or.id//teori dalam penelitian kualitatif.htm. di akses September 2008

Sugiono, Metode Penelitian Kuantitatif Kualitatif Dan R\&D, Alfabeta, Bandung, 2006

Widoyoko, EP, Analisis Kualitatif Dalam Penelitian Sosial, Bahan Kuliah Metodologi Penelitian FKIP Universitas Muhammadiyah Purworejo, 2007 